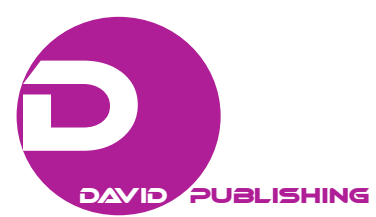

\title{
The European Neighborhood Policy as a Key Framework for Stability and Economic Cooperation
}

\author{
Redouane Mouhoub, Abdelmalek Debbihi \\ Bucharest University of Economic Studies ASE, Bucharest, Romania
}

\begin{abstract}
This article will discuss the manner in which the EU applies the European Neighbourhood Policy (ENP) by making a comparison between Southern Mediterranean and eastern European neighbouring countries. The ENP has been launched in 2003 and implemented in 2004 by the European Union (EU) to create an area of prosperity, stability, security and economic cooperation with neighbouring countries, with the objective of avoiding the emergence of new dividing lines between the enlarged EU and its neighbours. The way in which this policy has developed and the current challenges and threats faced by the EU and neighbouring countries after more than 10 years of its launch lead us to seek if this policy is implemented in the same way in different neighbouring countries and why it has not achieved its strategic objectives. The case study methodology focusing on Ukraine with comparison made with other countries of the neighbour especially Southern Mediterranean countries is used to argue findings related to the shortcomings in the implementation of the ENP. The analysis of the situation reveals that this policy is highly dominated by the EU's member countries in different neighbouring regions and by geo-strategic raisons. Decision-making process in EU institutions requires agreement of all EU countries for the decisions taken in the field of foreign policy and security. The consensus reached by EU countries to face together with the influence of Russia in eastern European countries, especially in Ukraine, gives EU institutions more prerogatives to manage the Ukrainian crisis and to have a very active diplomacy but with counterproductive results. However, the absence of geo-strategic competition in the Mediterranean region makes ENP more passive and the EU diplomacy overshadowed by the diplomacy of member countries facing conflicts erupted in that region.
\end{abstract}

Keywords: European Neighbourhood Policy (ENP), European Union (EU), Ukraine crisis, Eastern Partnership (EaP), Union for the Mediterranean (UfM), Arab spring

\section{Introduction}

The EU is considered as an important international actor. This position gives it the great responsibility to insure stability and prosperity in its neighbourhood. Conscious of this reality, the EU has implemented the European Neighbourhood Policy (ENP) to avoid new dividing lines between the widened Union and the countries in the vicinity. The European Union (EU) wishes to achieve this objective by exporting its values and its rules of the single market, while excluding membership option in this space using its soft power through its democratic, economic, and social development (Joannin, 2009).

Redouane Mouhoub, Ph.D. candidate, Bucharest University of Economic Studies ASE, Bucharest, Romania.

Abdelmalek Debbihi, Ph.D. candidate, Bucharest University of Economic Studies ASE, Bucharest, Romania.

Correspondence concerning this article should be addressed to Redouane Mouhoub, Str. Theodor Aman nr 4, Bucharest, Romania. 
However, the current situation in the countries of neighbourhood, after more than 10 years since the launch of this policy, proves that not only it did not achieve the main objective of stability and creation of an area of prosperity, but also did not prevent the destabilization of the neighbourhood and the explosion of violent conflicts. Even the use of restrictive measures which are considered as the powerful tool of the EU to implement its foreign policy (Duhamel, 2012) did not achieve results as expected. This situation leads us to analyse this policy to find out what is the obstacles for its implementation.

The implementation of this policy and its evolution confirm that it was a response to an urgent situation. As will be explained in below, the ENP has come to substitute the policy of enlargement, for the benefit of the Eastern Europe countries and in the same time has brought profound changes to the rules of cooperation with the countries of the Southern Mediterranean established by the Barcelona Process (1995).

Paradoxically, this policy which failed by its passivity to insure the stability of the neighbourhood and its prosperity, in particular the Southern Mediterranean, its implementation in the countries of the Eastern Europe provoked the outbreak of a conflict in Ukraine.

The ENP, which has been omnipresent in the implementation of the Oriental Partnership and the management of the Ukrainian crisis, was almost overlooked in the management of the migration crisis and conflicts that erupted in the Southern Mediterranean. The management of the "Arab Spring" was a victim of the unilateral conflict management by Member States without recourse to the EU institutions (Demesmay \& Sold, n.d.).

The current challenges in the neighbourhood, to which faces the EU, demonstrates that the ENP has not been prepared for these developments and that the legal and financial means of this policy are not living up to its ambitions and goals. This is due to the lack of an overall strategy in the field of foreign policy and security (Irving, 2012) and to the failure of the political union (Dehousse, n.d.). The launch by the European Commission of a reflection regarding the ENP reform, after the Ukrainian crisis, is the proof of its failure more than 10 years after its launch. However, every failure of the EU on the international scene is a factor for strengthening its foreign policy (Biava, 2005) and the reform of the ENP reflects that approach.

\section{Literature Review}

The International dimension of the EU has always been a subject of study focusing on the organisational and legal structure of the foreign policy of the EU (Irving, 2012), and on the political and security aspects of this policy (Dehousse, n.d.; Biava, 2005) addressing the major weaknesses of the political and security construction of the EU. These weaknesses are criticized taking in consideration the economical weight of the EU (Joannin, 2009). Joannin (2009) considers the economical power and values of the EU as the soft power of the Union. The concrete expression of this power are the restrictive measures (Duhamel, 2012), however, Marangé (2015) considers that the restrictive measures used against Russia did not resolve the crisis in Ukraine.

The studies focusing on the EU as an International actor, consider the ENP one of the core instruments of EU foreign policy. Studies on the ENP covered the issues related to its construction, organization, tools and its development (Lepesant, n.d.). The assessment of the implementation of this policy has become a topical issue after the eruption of conflicts in Southern Mediterranean countries and the in Ukraine. The ENP policy is discussed through the conflict analysis. Dotézac (2014), Lefort (2014) and De Murait (2014) have analyzed the causes and the management by the EU of the Ukrainian crisis. In addition, Matalan (2011), Demesmay and Sold (n.d.) have analyzed the reactions to the conflicts in Southern Mediterranean by the EU and member 
states.

This article will focus on the ENP, starting from the previous studies, to analyze the determinants and the approach of the EU within this policy to respond to the conflicts erupted in the neighboring countries by making comparison between Eastern European region and Southern Mediterranean region.

\section{The ENP: A Thoughtful Policy or an Alternative to Enlargement Policy}

The development of the neighbourhood policy raises some questions about the policy and the timing of its launch. At first glance, it seems that this policy intervened to complete the circle of cooperation with eastern neighbours after having formalized the cooperation with Southern Mediterranean countries under the Barcelona process. However, it came just after the EU noticed the impossibility to continue its enlargement policy.

Indeed, the formalization of the EU's relations with its neighbours does not date from 2004, and it goes back to 1995, with the launch of the Barcelona process. According to the Barcelona Declaration, the objective of this partnership is to create a space for dialogue, exchange, and cooperation to ensure peace into "a multilateral and sustainable framework of the relations established on a spirit of partnership, by taking into consideration the characteristics, values and peculiar features to each of the participants."

This partnership with the Mediterranean countries was based on four pillars (European Commission, n.d.) concerning the political and security, economic and financial, social and cultural fields, and finally immigration.

The launch of the ENP just after the 2004 enlargement was not a coincidence of date, but rather a response to the concerns about the EU's accession of 10 new members. It was also an alternative to the enlargement policy, proposed for the countries of Eastern Europe which have not acceded to the EU.

This policy has brought almost the same conditionality as it was the enlargement policy, which suggests that a future accession of the Eastern Europe countries is always predictable, despite the exclusion of the membership option in the neighbourhood policy. This is confirmed by the speech of the former President of the European Commission, Romano Prodi (2002) “... to share everything with the Union, except its institutions...”, "We have to be prepared to offer more than a partnership and less than a membership, without precluding the latter."

This speech which constitutes the basic reflection for the launch of the ENP answered essentially to the questions asked by Mr Prodi: "What have we to offer our new neighbours in a near future? What prospects can we hold out to them? Where does Europe end? These are the questions we have to answer. The European public is calling for such a debate. I know this debate will heat up after the accession of new members. Therefore it is our duty to start finding some answers."

These responses have taken shape in 2004 in the ENP, confirming that this policy is intended primarily to the countries of Eastern Europe to prepare them for an eventual membership without an express commitment taken by the EU.

Southern Mediterranean countries, whose relations were framed by a neighbourhood policy peculiar to this region even before the 2004 enlargement, were included in this policy to provide a comprehensive and consistent dimension to the EU policy towards its neighbourhood from the east and the south, even the Union for the Mediterranean (UfM), which was only a proposal encompassing the Mediterranean countries, has been appropriated by the EU. However, the new ENP has brought major changes to the cooperation framework provided by the Barcelona Process. It dedicates the de facto unilateral aspect of this policy, which is designed only by the EU and proposed to neighbouring countries, while the Barcelona process was a partnership 
negotiated multilaterally with the consent of the Mediterranean countries.

The five-year work program (European Commission, 2005) adopted at the Barcelona Summit on the occasion of the celebration of 10 years of Euro-Mediterranean partnership within the framework of the 1995 Declaration, states that the cooperation respect "the national priorities, and based on the commitment of the countries in the region to reform, included in the Tunis Declaration".

However, the ENP, as a response to the Eastern Europe countries, was part of the process of enlargement policy, which had as engine the membership perspective. Nevertheless, the ENP poses conditionality reforms without this prospect according to the European Commission communication text on enlarged Europe-Neighbourhood: A New Framework for the Relations with our East and South neighbours (2003, p 16), it is stated that "... This implies the partners taking on considerably deeper and broader obligations, specifically when it comes to align with Community legislation".

Therefore, EU proposes in the ENP to export its model and its values to neighbouring countries. In the absence of a prospect of membership, EU aims to be itself as an attractive target for neighbourhood countries using its soft power (Joannin, 2009) following the formula "sharing everything but institutions" including the sharing of principles, values, and standards of EU.

Boniface (2007) considers that the ENP, which addresses in the same manner to countries whose aim is to join the EU, as the case of some countries of Eastern Europe or countries that are not sharing the same goal or simply are not eligible for membership, was the case of the countries of the Southern Mediterranean, with risks displeasing the first ones and arousing the distrust of the second.

The idea to realize the ENP with the same objectives as that of the enlargement policy has created confusion among the neighbouring countries and has brought major changes in the perception of the nature of cooperation between EU and its neighbours. The most effective instruments at the disposal of this policy are the financial instrument and the bilateral association agreements. For Southern Mediterranean countries, such instruments already exist, however, the framework of cooperation with EU has become increasingly unilateral and constraining, against a significant decline in multilateral dialogue framework provided by the Barcelona Process. However, for the Eastern Europe countries, which hoped to join the EU, the new proposal hardly changed their perception as for their relationship with the EU which remains conditioned by a future accession to this space. This sense of belonging to the EU was the mainspring of pro-European protests in Ukraine.

\section{The Conflicts in the Mediterranean and the ENP's Passivity}

The EU in its relations with its neighbours faced many challenges and disparities in level of development which separate it from neighbouring countries (Lepesant, n.d.). The subsequent developments in the Southern Mediterranean region have surprised EU and the Member States.

Tisseron (2011) distinguishes three stages in the EU's response to the revolts and revolution in the Arab world. Between late 2010 and early 2011, the EU feels overtaken by events and regrets not having included the political reforms conditionality of the partner countries to activate the European support. Secondly, the EU wanted to catch and mark its presence by humanitarian aid granted to Tunisia ( $€ 17$ million) and Libya ( $€ 30$ million) and statements condemning the Libyan, Tunisian, Egyptian, and Syrian regimes and the adoption of a series of sanctions against the Libyan regime.

Thirdly, the EU announced the reorientation of the ENP from a financial point of view by announcing an additional $€ 1.2$ billion to more than $€ 5.7$ billion available for period 2011-2013 and launched, in parallel, a new 
EU strategy towards neighbouring countries in the South as in the East.

Indeed, after the Arab revolts, the EU (2011a) launched the "Partnership for Democracy and Shared Prosperity with the Southern Mediterranean" hinged on democratic transformation and a strengthening of institutions, a stronger partnership with the people as well as on a growth, sustainable and inclusive economic development. Through this partnership, EU wishes to adopt a differentiated strategy by conditioning the strengthening of partnerships with the neighbouring countries by achieving concrete progress in the political reforms in the areas of democracy, human rights, good governance, and rule of law.

This partnership came to strengthen the principle "more for more" and to devote the unilateral aspect of the ENP giving to the EU the diffuser's role of values and prosperity by using of its soft power. Indeed, the text of this partnership clearly states that "It is an incentive-based approach based on more differentiation ("more for more"): those (neighbouring countries) who go further and faster with reforms will be able to count on greater support from the EU. Support will be reallocated or refocused for those who stall or retrench on agreed reform plans.

This proposed partnership is offered as "reward" for countries that achieve the desired reforms by the EU, the resumption of the negotiations on the association agreements for an "advanced status" which enables a more meaningful dialogue between the partner countries and EU's institutions.

The Triangle Funding-mobility-markets, proposed within the framework of this partnership has been specified in the EU's Joint Communication (2011b) marking the launch of "a new strategy with regard to a Neighbourhood in transformation".

However, the initiative undertaken by the EU after the revolts and conflicts triggered in the Southern Mediterranean joins rather in the logic of what should be the partnership with the neighbourhood of the Southern Mediterranean and not in a vision on what to do to stabilize the region and find peaceful solutions to conflicts. This approach conceals a sense of regret and a desire to catch up with the rapid developments in this area.

In efforts to conflicts resolution in the region, EU diplomacy was overshadowed by the diplomacy of member countries. The discrepancy between the Member States's foreign policies and the EU's has become visible more than ever during the "Arab Spring". Some policies to settle those conflicts have been adopted at national level by Member States and then submitted at the EU institutions level, to snatch a consensus and a European support as it was the case of the French proposal to intervene in Libya, adopted by the United Nations Security Council, but it has not reached consensus at European level, especially after the opposition of Germany (Matalan, 2011). The couple Franco-German has shown disagreement and a lack of cooperation in conflict management in the Southern Mediterranean area (Demesmay \& Sold, n.d.).

The new EU proposal for partnership with the countries of the Southern Mediterranean is therefore only a future vision of the bases for cooperation between the Union and Mediterranean neighbouring countries. Conditioning EU support for political reforms in the partner country has, in fact, only a limited impact, because these countries are more concerned about the internal situation than by the EU's financial assistance proposals. Moreover, the EU's new vision for the ENP has not had a positive impact in the Eastern Europe region as the Ukraine case study shows.

\section{Ukraine: The Straw That Broke the Camel’s Back}

Contrary to the passivity of the EU's foreign policy dealing with conflicts in the Southern Mediterranean 
region, this one was rather aggressive in the Eastern European region, within the framework of the Oriental Partnership. The strengthening of the Eastern Partnership proposed in the document "a new strategy towards a neighbourhood in transformation" was immediately implemented by the EU's institutions which have accelerated their diplomatic pressure to result in the signing of agreements association with the Eastern Europe countries. This is considered as an important stage in achieving the ENP's objectives with the new neighbours following the EU's 2004 enlargement, especially to create a space of stability and prosperity. However, this policy has paradoxically caused the opposite. The signing of the Association Agreement with Ukraine has plunged the country into instability and caused the deterioration of relations between EU and Russia, creating a new line of division between this Union and a great neighbour.

The scenario according to which the situation in Ukraine developed after the summit of Vilnius was simply unpredictable for Ukrainian, European as well as for the Russian.

A chronological reading about the beginnings of the current crisis in Ukraine highlighted a conflict of interest between the European and the Russian as well as between the pro-European and pro-Russian Ukrainian components with direct consequences on the stability of Ukraine.

Right after the decision taken by the Ukrainian authorities, on 21 November 2013, to suspend the preparations for the signing of the association agreement in Vilnius Summit (28 and 29 November 2013), pro-European protesters gathered on Maidan, in Kiev, to claim their belonging to Europe and to urge the Ukrainian government to change its attitude. These events were described by the EU, that noted in the joint declaration of the Vilnius Summit on the oriental Partnership, as "the unprecedented public support for political association and economic integration of Ukraine into the EU" (Council of the European Union, 2013).

The Russians who were surprised by the events of "Maidan" hurriedly supported their diplomatic success to keep Ukraine in the Eurasian project by granting, on 24 December 2013, three (03) billion dollars (2.2 billion Euros) representing the first tranche of the financial rescue plan of 15 billion dollars (11 billion Euros) under the agreement signed on 17 December 2013 in Moscow between the Ukrainian and Russian presidents (Le Monde, 2013).

On the European side, by using of restrictive measures tool (Duhamel, 2012), sanctions have been taken against those responsible for violence (Council of the European Union, 2014). In addition, European and American officials also increased pressure on the government and the Ukrainian President and they have multiplied their travels widely publicized, while openly providing support to pro-European protesters in Ukraine.

However, the events have accelerated until the dismissal, on February 22nd 2014 of the Ukrainian President Yanukovych (Le Huffington Post, 2014), followed by the annexation of the Crimea by Russia, by signing on March 21st 2015 by the Russian President of the law planning the creation of two Russian administrative entities, namely Crimea and Port of Sevastopol (Le Monde, 2014).

The EU, which immediately condemned the annexation of Crimea by Russia, signed on 21st March 2014, the first part of the Association Agreement with Ukraine (European Council, 2014) followed by the final signing of the Association agreement 27th June 2014 (European Commission , 2014). On May 11th 2014, the referendum of self-determination have been organized by the separatists and that gave victory to the "Yes" by $89 \%$ in the "People's Republic of Donetsk" and 96\% in the "People's Republic of Luhansk" (Baczyńska, Polityuk, \& André, 2015) which led to the outbreak of armed conflict in Eastern Ukraine.

It is clear that the EU policy with its neighbours of Eastern Europe was lacking visibility. Certainly it was 
more active with regard to that intended for the neighbourhood of the Southern Mediterranean and made a big step forward by signing the association agreements with the countries of the Eastern Partnership (Ukraine, Georgia, and Moldova), however, it obtained counterproductive and irreversible results. The same ENP which is supposed to ensure stability and security in the neighbourhood caused the disorder, instability, and insecurity in Ukraine and a deterioration of the relations with the Russian neighbour, an economic and military giant and the main supplier of energy to Europe.

Indeed, according to the report of the House of Lords of Great Britain (2015) on the relations between EU and Russia, a "significant error" of analysis was committed by the EU concerning Ukraine which neglected the warning signals. The report of the House of Lords revealed that the EU member countries have demonstrated a lack of good information gathering and a lack of coordination in their foreign policy. They overestimated at the same time the intentions of the Ukrainian leaders to sign the Association Agreement, showed ignorance to the Ukrainian public, and underestimated Russia's hostility to the Association Agreement.

The failure of the EU's approach to its neighbourhood was confirmed by the launch of a consultation on the reform of the ENP following the consultation document of the European Commission (2015a) entitled "Towards a new neighbourhood policy". This document leaves no room for doubt; ENP needs to be revised.

\section{Conclusion}

The main objective of the ENP, to create an area of stability and prosperity, since its launch in 2004, was a failure by its passivity, as in the case of the Southern region of the Mediterranean, or by its dynamism, in the case of Eastern Europe. This policy was not able to prevent armed conflicts in the Southern Mediterranean countries and, ironically, caused the outbreak of an armed conflict in Ukraine, and the deterioration of the relations with the Russian neighbour.

Indeed, the Ukrainian crisis has revealed the limits of the ENP and was the triggering event of its revision. The document "Towards a new neighbourhood policy" criticizes almost all unilateral aspects based on a European offer which did not completely involve the partner countries. The aspirations of the partner countries are often not taken into account under the framework proposed by the ENP. This can be explained by its anarchic development to seek an alternative to enlargement policy, and to be proposed to the new Eastern Europe neighbours. It included the countries of the Mediterranean framed earlier by the Barcelona Process, which worked rather well, with the objective to have a single policy for all the neighbouring countries.

Since its launch ENP had a lack of clarity, visibility, and resources as well as a long-term strategy, it brought new conditions to the cooperation with the Mediterranean countries in order to prepare, within its overall neighbourhood policy, the countries of Eastern Europe for an eventual membership. Also, this policy remains ambiguous about what fuelled most of the aspirations of the Eastern Europe countries to adhere to EU, and provoked some confusion in the Mediterranean neighbourhood.

The ENP has shown that it is an instrument of the EU's foreign policy rather than a framework for cooperation. Conceived to develop privileged relations with the countries of the neighbourhood and to establish an area of prosperity, the ENP has turned to an instrument of response to emergency situations or an instrument of influence.

The ENP's revision project proposed by the European Commission (2015b) gives as the main role of the ENP, the stabilization of the neighbourhood. This new policy aims to be more cooperative, basing itself on the principle of differentiation and ownership of this policy by member countries and partners. It comes also to 
ensure economic stabilization of the partner countries, which had been neglected in the ENP, and to give special attention to the neighbourhood of the neighbourhood. However, the ENP's reform necessarily involves strengthening the EU's foreign policy.

\section{References}

Baczyńska, G., Polityuk, P., \& André, H. (2015). Chronologie de la crise en Ukraine, Challenges [Chronology of the crisis in Ukraine, challenges]. Retrieved from http://www.challenges.fr/monde/20150207.REU9336/chronologie-de-la-crise-en-ukraine.html

Biava, A. (2005). L’Union européenne, acteur global? Potentialités et limites de la PESC et de la PESD [The European Union, a global player? Potential and limits of the CFSP and ESDP]. Euryopa, 31, 1-147. Retrieved from https://www.unige.ch/gsi/files/3314/0351/6378/BIAVA.pdf

Boniface, J. (2007). La politique européenne de voisinage, entre élargissement et politique étrangère [The European Neighbourhood Policy, between enlargement and foreign policy]. Eipascope, 1, 25-31.

Commission Européenne [European Commission]. (2003). l'Europe Elargie-voisinage: un nouveau cadre pour les relations avec nos voisins de l'Est et du Sud. Communication de la Commission au Conseil et au Parlement européen. Bruxelles. [Wider Europe-Neighbourhood: A new framework for relations with our neighbors to the East and South. Communication from the commission to the council and the European parliament. Brussels.]. Retrieved from http://eeas.europa.eu/enp/pdf/pdf/com03_104_fr.pdf

Commission Européenne [European Commission]. (2011a). Un partenariat pour la démocratie et une prospérité partagée avec le sud de la méditerranée. Communication conjointe au conseil européen, au parlement européen, au conseil, au comité économique et social européen et au comité des régions. [A partnership for democracy and shared prosperity with the Southern Mediterranean. Joint Communication to the European Council, the European Parliament, the Council, the European Economic and Social Committee and the Committee of the Regions]. Retrieved from http://eur-lex.europa.eu/LexUriServ/LexUriServ.do?uri=COM:2011:0200:FIN:FR:PDF

Commission Européenne [European Commission]. (2011b). Une stratégie nouvelle à l'égard d'un voisinage en mutation. Examen de la PEV. Communication conjointe de la Haute Représentante de l'Union pour les Affaires étrangères et la politique de la sécurité et de la Commission Européenne. Bruxelles. [A new strategy towards a changing neighbourhood. Review of the ENP joint communication of the high representative of the Union for Foreign Affairs and Security Policy and the European Commission. Brussels]. Retrieved from http://eeas.europa.eu/enp/pdf/pdf/com_11_303_fr.pdf

Commission Européenne [European Commission]. (n.d). Le processus de Barcelone [The Barcelona Process]. Retrieved from http://eeas.europa.eu/euromed/barcelona_fr.htm

Council of the European Union. (2013). Eastern partnership: The way ahead. Joint declaration of the eastern partnership summit. Vilnius.

Council of the European Union. (2014). Council conclusions on Ukraine foreign affairs council meeting. Brussels.

Dehousse, R. (n.d). L'Europe politique a-t-elle encore un avenir? [Political Europe does still have a future]. L'Union européenne, acteur des relations internationales (pp. 530-545). Retrieved from http://www.diplomatie.gouv.fr/fr/IMG/pdf/03.03.pdf

Demesmay, C., \& Sold, K. (n.d). Réactions au Printemps arabe: à la recherche du plus petit dénominateur commun [Reactions to the Arab Spring: Looking for the lowest common denominator]. Réactions au printemps arabe. (pp. 69-83). Retrieved from https://gap.org/sites/default/files/article_downloads/reactions_au_printemps_arabe_claire_demesmay_katrin_sold.pdf

De Murait, F. (2014). L'occident n'a-t-il pas fait l'erreur de trop en Ukraine? [The western world did not do a big mistake]. Market, 115, 11-12.

Dotézac, A. (2014). L’Ukraine: une crise sous influence [Ukraine: Crisis under influence]. Market, 115, $22-25$.

Duhamel, S. (2012). L'usage des mesures restrictives autonomes de l'Union européenne: deux poids deux mesures ou des mesures de poids? EU Diplomacy Paper. Department of EU international relations and diplomacy studies. Retrieved from https://www.coleurope.eu/system/files_force/research.../edp_9_2012_duhamel.pdf

European Commission. (1995). Barcelona Declaration adopted at the Euro-Mediterranean Conference 27-28/11/95. Retrieved from http://trade.ec.europa.eu/doclib/docs/2005/july/tradoc_124236.pdf

European Commission. (2005). Five year work programme: Euromed. Retrieved from http://eeas.europa.eu/euromed/summit1105/five_years_en.pdf

European Commission. (2014). EU forges closer ties with Ukraine, Georgia and Moldova. Retrieved from 
http://www.eeas.europa.eu/top_stories/2014/270614_association_agreement_en.htm

European Commission, High Representative of the European Union for Foreign Affairs and Security Policy. (2015a). Towards a new European neighbourhood policy. Joint Consultation Paper. Brussels.

European Commission. (2015b). Review of the European Neighbourhood Policy. Joint communication to the European parliament, the council, the European economic and social committee and the committee of the regions. Retrieved from http://eeas.europa.eu/enp/documents/2015/151118_joint-communication_review-of-the-enp_en.pdf.

European Council. (2014). Statement by President of the European Council Herman Van Rompuy at the occasion of the signing ceremony of the political provisions of the association agreement between the European Union and Ukraine. European Council. Brussels.

House of Lords. (2015). The EU and Russia: Before and beyond the crisis in Ukraine. European Union Committee 6th Report of Session.

Irving, L. (2012). L’Union Européenne comme acteur international vingt ans après Maastricht : le service européen pour l'action extérieure et le défi d'une diplomatie cohérente et efficace [The EU as an international actor twenty years after Maastricht: European service for external action and the challenge of a coherent and effective diplomacy]. Revue québécoise de droit international, 73-83. Retrieved from http://www.sqdi.org/wp-content/uploads/HS-UE_07_Lewis.pdf

Joannin, P. (2009). L'Europe en 2025: géant économique, nain politique? [Europe 2025: Economic giant, political dwarf?]. Géoéconomie, 50, 79-85. Retrieved from http://www.cairn.info/revue-geoeconomie-2009-3-page-79.htm

Lefort, P. (2014). La crise ukrainienne ou le malentendu européen [Ukrainian crisis and the European misunderstanding]. Politique étrangère, 79(2), 109-121.

Le Huffington Post. (2014). Ukraine: Ianoukovitch destitué, Timochenko libérée et acclamée à Kiev [Ukraine: Yanukovich dismissed, Tymoshenko released and acclaimed in Kiev]. Retrieved from http://www.huffingtonpost.fr/2014/02/22/direct-ukraine-ianoukovitch-timochenko_n_4837040.html?utm_hp_ref=france

Le Monde. (2013). La Russie verse 3 milliards de dollars à l'Ukraine [Russia pays \$ 3 billion to Ukraine]. Retrieved from http:/www.lemonde.fr/europe/article/2013/12/24/la-russie-verse-3-milliards-de-dollars-a-1-ukraine_4339624_3214.html

Le Monde. (2014). La Russie complète l'annexion de la Crimée [Russia completes the annexation of Crimea]. Retrieved from http://www.lemonde.fr/europe/article/2014/03/21/1-annexion-definitive-de-la-crimee-au-bout-du-stylo-de-poutine_4387210_ 3214.html

Lepesant, G. (n.d). l'Union Européenne et son voisinage: vers un nouveau contrat [The European Union and its neighbourhood: Towards a new contract]. Retrieved from http://www.diplomatie.gouv.fr/fr/IMG/pdf/0105LEPESANT-FR2.pdf

Marangé, C. 2015. Les sanctions contre la Russie ont-elles un effet dissuasif? [Sanctions against Russia: Have they a dissuasive effect]. Etudes de l'IRSEM, 37, 1-44.

Matalan, V. (2011). Libye: l'intervention militaire en questions [Libya: Military intervention in questions]. Le Monde.fr. Retrieved from http://www.lemonde.fr/afrique/article/2011/03/18/libye-1-intervention-militaire-en-questions_1494988_3212.html

Prodi, R. (2002). L'Europe élargie-une politique de proximité comme clé de la stabilité, Paix, sécurité et stabilité, dialogue international et rôle de l'UE, discours pour la 6e conférence mondiale du réseau ECSA. Bruxelles. [Wider Europe-a proximity policy as the key to stability, peace, and security, dialogue and international role of the EU, to address the 6th World Conference ECSA. Brussels]. Retrieved from http://europa.eu/rapid/press-release_SPEECH-02-619_fr.pdf

Tisseron, A. (2011). L'Union européenne face au "printemps arabe": une nouvelle stratégie et des incertitudes. [The European Union and the "Arab spring": A new strategy and uncertainty]. Institut Thomas More. Retrieved from http://www.institut-thomas-more.org/upload/media/tisseron-septembre2011.pdf 